\title{
Lessons Learned from Gastric Bypass Operations in Rats
}

\author{
Florian Seyfried ${ }^{a, b}$ Carel W. le Roux ${ }^{a} \quad$ Marco Bueter $^{a, c}$ \\ a Imperial Weight Centre, Department of Investigative Medicine, Imperial College London, London, UK \\ ${ }^{\mathrm{b}}$ Department of Surgery, University of Würzburg, Würzburg, Germany \\ 'Department of Surgery, University Hospital Zürich, Zürich, Switzerland
}

\section{Keywords}

Animal model - Experimental design of rodent studies . Surgical technique - Gastric bypass .

Roux-en-Y gastric bypass

\section{Summary}

Numerous studies using gastric bypass rat models have been recently conducted to uncover underlying physiological mechanisms of Roux-en-Y gastric bypass. Reflecting on lessons learned from gastric bypass rat models may thus aid the development of gastric bypass models in mice and other species. This review aims to discuss technical and experimental details of published gastric bypass rat models to understand advantages and limitations of this experimental tool. The review is based on PubMed literature using the search terms 'animal model', 'rodent model', 'bariatric surgery', 'gastric bypass', and 'Roux-en-Y gastric bypass'. All studies published up until February 2011 were included. 32 studies describing 15 different rat gastric bypass models were included. Description of surgical technique differs in terms of pouch size, limb lengths, preservation of the vagal nerve, and mortality rate. Surgery was carried out exclusively in male rats of different strains and ages. Pre- and postoperative diets also varied significantly. Technical and experimental variations in published gastric bypass rat models complicate comparison and identification of potential physiological mechanisms involved in gastric bypass. In summary, there is no clear evidence that any of these models is superior, but there is an emerging need for standardization of the procedure to achieve consistent and comparable data.

\section{Introduction}

Currently, the most effective therapy for morbid obesity is bariatric surgery $[1,2]$ with Roux-en-Y gastric bypass (gastric bypass) being the most common operation performed [3]. Gastric bypass has been shown to ameliorate or even cure obesity-related comorbidities such as type 2 diabetes or sleep apnea $[1,4]$. The physiological mechanisms by which gastric bypass surgery works are not yet fully understood. The success of gastric bypass was previously attributed to mechanical restriction through reduction of gastric volume as well as calorie malabsorption secondary to the bypass of the duodenum and proximal jejunum [5]. The emerging consensus is that the gastric bypass (fig. 1) is an operation consisting of at least 5 components [6, 7]: i) reduction of stomach size; ii) exclusion of stomach and first part of small bowel from nutrients; iii) bile flow alteration; iv) earlier contact of nutrients with mid gut; and v) disruption of gastric branches of the vagal nerve. These components act most likely in concert to impact on gastrointestinal and central neuroendocrine signaling leading to alterations in energy homeostasis [8-10]. Mechanisms contributing to postoperative body weight loss may include reduced hunger and increased satiation [9], increased energy expenditure $[10,11]$, altered food preference $[10,12,13]$, altered insulin secretion and increased insulin sensitivity [14-16]. The relative impact of each particular component remains unclear.

During the last 2 decades, numerous studies using rats have been carried out to investigate physiological changes after gastric bypass (table 1). The gastric bypass rat model is a valuable tool as it closely mimics the time profile and magnitude of human weight loss $[14,15,17-23]$ and allows researchers to control and manipulate critical anatomic and physiologic factors. Consequently, there is a wide array of rat gastric bypass models available in the literature (table 1 ). In addition, gastric bypass mouse models have attracted major interest to further

\section{KARGER \\ Fax +497614520714 \\ Information@Karger.de}

www.karger.com (c) 2011 S. Karger GmbH, Freiburg

$1662-4025 / 11 / 0047-0003 \$ 38.00 / 0$

Accessible online at:

www.karger.com/ofa
Dr. Marco Bueter

Department of Surgery, Division of Visceral and Transplantation Surgery University Hospital Zürich

Raemistrasse 100, 8091 Zürich, Switzerland

Tel. +4144 255 8-895, Fax -941

marco.bueter@usz.ch 
elucidate physiological changes for example in knock-out animals [24]. Thus far, only duodenojejunal exclusion models in mice have been published [24-27], most likely because gastric bypass mouse models are technically demanding [27]. Reflecting on the lessons learned from gastric bypass rat models may help to develop mice and other models in the future. This review therefore aims to summarize and discuss technical and experimental details of gastric bypass rat models available in the literature to highlight the advantages and limitations of the current models. 32 studies identified by performing a PubMed literature search (www.ncbi.nlm.nih.gov/pubmed/) using the search terms 'animal model', 'rodent model', 'bariatric surgery', 'gastric bypass', and 'Roux-en-Y gastric bypass' were included. All studies were published before February 2011 and described a total number of 15 different rat models of gastric bypass.

\section{Surgical Principles of Roux-en-Y Gastric Bypass}

The Roux-en-Y gastric bypass procedure in humans was first described by Mason et al. [28] in 1967. The procedure consists of a small gastric pouch and the bypass of the proximal small bowel (fig. 1a). The former was initially labeled as the restrictive component because of the smaller storage capacity in the pouch and the limitation of nutrient flow through the gastrojejunostomy through which ingested foods are emptied from the pouch into the jejunum ('Alimentary limb', length $75-250 \mathrm{~cm})$. The latter was initially considered the malabsorptive part of the gastric bypass operation as the stomach remnant, the duodenum, and the proximal jejunum are bypassed by nutrients. This bypassed part of the gastrointestinal tract forms the so-called 'biliopancreatic limb' because bile acids as well as pancreatic enzymes are secreted into the duodenum. The biliopancreatic limb is joined downstream to the alimentary limb by a jejunojejunal anastomosis to form the 'common channel' delaying mixture of ingested food with bile and digestive enzymes (fig. 1a).

\section{Differences in Surgical Technique of Published Gastric Bypass Rat Models}

\section{Pouch}

The gastric bypass operation in humans creates a small gastric pouch $(20-50 \mathrm{ml})$ with very limited food storage capacity [29, 30]. Mason et al. [5] reported that a large pouch size causes insufficient weight loss or weight regain and therefore suggested a pouch size of less than $50 \mathrm{ml}$. A negative correlation between pouch size and body weight loss after gastric bypass has also been described by Roberts et al. [31], but this remains controversial $[29,30]$. The creation of a small gastric pouch in rats is technically demanding and a variety of different techniques has been described (table 1). The pouch size of the a

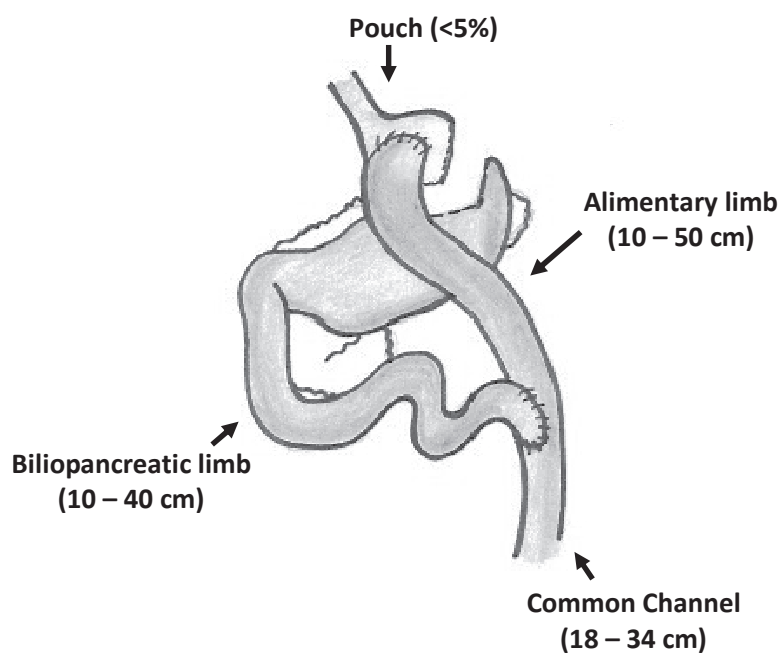

b

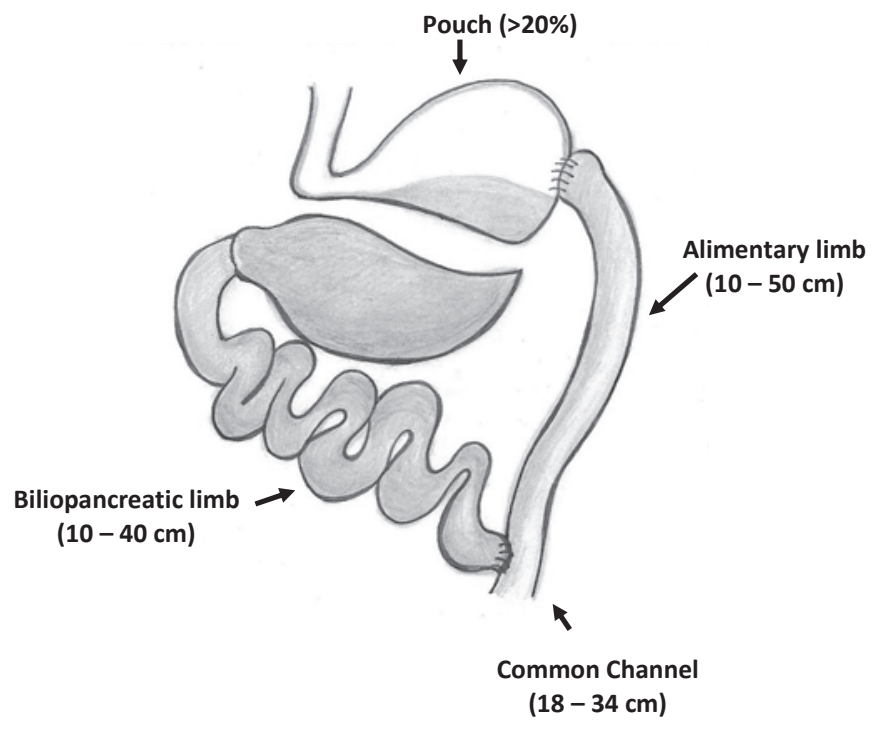

Fig. 1. Schematic illustration of gastric bypass models using a gastric pouch of less than $5 \%$ (a) and of about $20 \%$ (b) of the original stomach size.

reported gastric bypass models in rats ranges from $5 \%$ (fig. 1a) to more than $20 \%$ (fig. 1 b) of the initial stomach size [17, 32, 33]. Most authors transect the stomach by using stapler devices or microsurgical scissors (table 1). To avoid bleeding from the stomach, the stapler line is sown over in some models [21, 34]. The ligation of left gastric vessels can help to avoid bleeding, but can cause ischemia of the remnant stomach $[21,34]$. Therefore, gentle mobilization of the main vessel by cauterizing tributaries and branches without dissection or ligation has been reported $[17,18]$, while Tichansky et al. [34] performed a partial resection of the remnant stomach to avoid necrosis.

In contrast to gastric bypass in humans, most of the published rat gastric bypass models preserve a stomach pouch of at least $20 \%$ of the original volume (table 1 ). Gastric bypass 


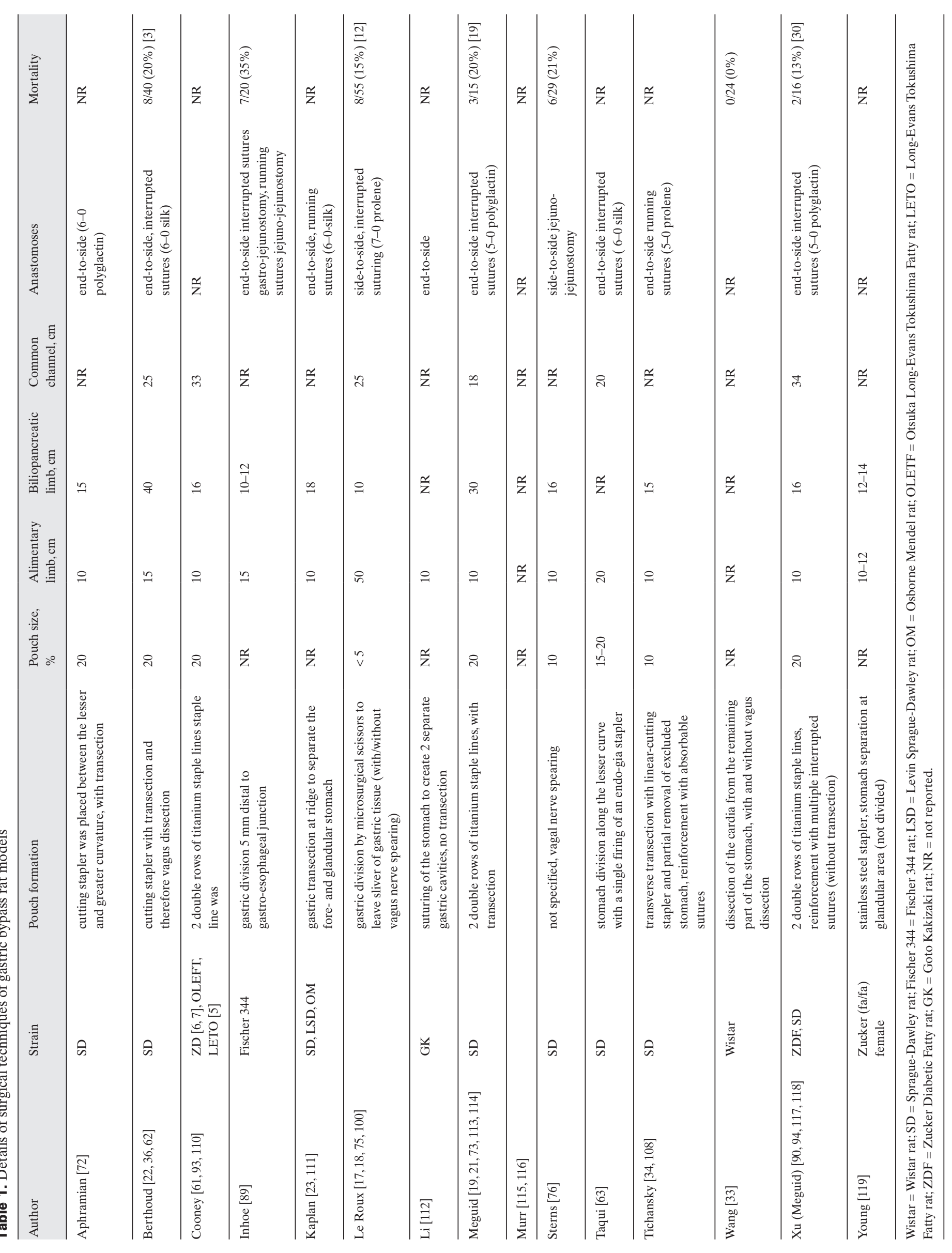


rats with a pouch of $20 \%$ or more of the original stomach size retain ingested contrast medium in their pouch long after ingestion has stopped [23]. Thus, the pouch may retain storage capacity, consequently resulting in a different physiological state compared to human gastric bypass. Other gastric bypass rat models reported a pouch size between $5 \%[17,18]$ and $10 \%$ [35] demonstrating reductions in food intake varying from little [35] to significant $[17,18]$. To investigate whether the small pouch causes restriction, we compared the food intake of gastric bypass rats after a 1-day starvation period. Gastric bypass rats were able to eat significantly more than ad libitum fed sham-operated rats (unpublished data) suggesting that the restrictive component may be overestimated and that reduced motivation may be more important than physical ability to eat after gastric bypass. However, the food intake of gastric bypass rats seems to be reduced independently of the gastric pouch size $[17,21,34,35]$, although meal size became smaller while animals ate more frequently $[18,36]$.

\section{Limb Length}

The impact of the different intestinal limb lengths in terms of body weight loss in humans remains controversial and some authors still favor an alimentary limb length $(75-150 \mathrm{~cm}) \mathrm{de}-$ pendent on the preoperative body weight [37-39]. Randomized controlled trials suggest that a length of the alimentary limb between 75 and $150 \mathrm{~cm}$ does not predict body weight loss or the improvement of obesity-related comorbidities in humans after gastric bypass [37, 40-43]. In contrast, Pinheiro et al. [44] have shown that gastric bypass with an alimentary limb of $250 \mathrm{~cm}$ may be superior for type 2 diabetes, lipid disorders, and body weight loss in the short term. Caloric malabsorption may account for $6-11 \%$ of the total reduction in energy absorption after long limb Roux-en-Y gastric bypass in humans [45]. A longer alimentary limb may thus introduce caloric malabsorption and lead to greater body weight loss.

There are considerable differences in the limb lengths across the available gastric bypass rat models with an alimentary limb varying between 10 and $50 \mathrm{~cm}$, the biliopancreatic limb length ranging between 10 and $40 \mathrm{~cm}$ and a common channel between 18 and $34 \mathrm{~cm}$ (table 1). Significant caloric malabsorption has however been excluded by bomb calorimetry even in the short common channel $(25 \mathrm{~cm})$ gastric bypass models eating normal low fat chow $[18,35]$. In animals fed a high fat chow, a small amount of malabsorption for fat has been demonstrated even in models with a long common channel (approximately $50 \mathrm{~cm}$ ) [23]. Thus, malabsorption may relate more to dietary fat content than to limb length. Guiarro et al. [19] reported a significantly increased fecal output accompanied by malabsorption of fat in normal chow fed gastric bypass rats with a biliopancreatic limb of $30 \mathrm{~cm}$ and a common channel of $18 \mathrm{~cm}$, which is reminiscent of a malabsorptive biliopancreatic diversion rather than of a Roux-en-Y gastric bypass [46].

\section{Bile Flow Alterations}

The altered nutrient flow and in particular the altered bile flow after gastric bypass may also contribute to metabolic changes [47-49]. It should be emphasized that contrary to the traditional view bile does not function simply as a fat solubilizer, but also influences cholesterol and glucose metabolism by acting on nuclear receptors [50]. Bile has also been shown to modulate energy expenditure by stimulating brown adipose tissue and skeletal muscle via activation of the G-proteincoupled receptor TGR5, which is also expressed on the surface of enteroendocrine L-cells [49, 51]. Alterations in bile acid metabolism have not been addressed in any of the reviewed rodent studies, but given the differences in limb lengths between the different bypass rat models, it seems plausible that bile acid metabolism may be altered.

\section{Gut Hormone Alterations}

Altered levels of gut hormones after gastric bypass to humans have been previously reported $[52,53]$. However, it is unclear whether bypassing the hormonally active duodenum and proximal jejunum or increasing the delivery of undiluted bile and undigested foods to the distal small bowel, or both, stimulate the enteroendocrine L-cells to secrete gut hormones such as peptide YY (PYY) and glucagon-like peptide 1 (GLP-1) $[49,54]$. Elevated levels of PYY and GLP-1 lead consequently to increased satiety and reduced hunger thought to be through actions on the hypothalamic arcuate nucleus and paraventricular nucleus, respectively $[55,56]$. PYY, released postprandially from the distal gastrointestinal tract, decreases expression of the orexigenic hypothalamic neuropeptide $\mathrm{Y}$ (NPY) and inhibits food intake. Peripheral administration of PYY3-36 and GLP-1 in humans and rodents reduces food intake [57, 58]. GLP-1 also acts as an incretin-promoting postprandial insulin release [59] and improves pancreatic cell function [60]. Some but not all of the reported rat models of gastric bypass reported alterations in gut hormone levels. Upon further scrutiny, elevated levels of PYY and GLP-1 were found in both fasting [17] and fed rats [17, 61-63] after gastric bypass (table 2).

So far, ghrelin is the only known orexigenic enteropeptide $[64,65]$. Ghrelin is mainly produced from the fundus of the stomach and the oral small intestine $[52,66]$. Ghrelin might play a role in meal initiation as its levels are increased prior to a meal [67]. Postprandially, ghrelin levels are suppressed proportional to the caloric content of the ingested foods [68]. Available data on ghrelin levels after gastric bypass in humans are inconclusive, as decreased [52,69], unchanged [8,9], or even increased $[70,71]$ levels have been observed postoperatively in humans. Similarly, ghrelin levels after gastric bypass in rats also show great variations [33, 72, 73]. Postoperative alterations in gut hormone levels after gastric bypass in rats are summarized in table 2 . The effect of gastric bypass surgery on gut hormone levels has been systematically reviewed elsewhere [6]. 
Table 2. Body weight loss, food intake and gut hormones of gastric bypass models

\begin{tabular}{|c|c|c|c|c|c|}
\hline \multirow[t]{2}{*}{ Institution } & \multicolumn{2}{|c|}{ Body weight, \% } & \multirow[t]{2}{*}{ Weight plateau } & \multirow[t]{2}{*}{ Food intake, $\%$} & \multirow[t]{2}{*}{ Hormonal response (fasting) } \\
\hline & $<2$ weeks & $>2$ weeks & & & \\
\hline Aphramian [72] & -15.1 & - & - & - & ghrelin $\uparrow$ \\
\hline Berthoud $[22,36,62]$ & -20 & 23 & yes & -20 & $\begin{array}{l}\text { GLP-1 }(\uparrow) \uparrow, \text { PYY }(\leftrightarrow) \uparrow, \text { ghrelin }(\leftrightarrow) \leftrightarrow, \\
\operatorname{GIP}(\leftrightarrow) \leftrightarrow, \text { leptin } \downarrow[3]\end{array}$ \\
\hline Cooney $[61,93,110]$ & $\begin{array}{l}-9 /-6[6,7] \\
-20 / 16[5]\end{array}$ & $\begin{array}{l}-13 /-8 \\
-26\end{array}$ & $\begin{array}{l}\text { yes } \\
\text { yes }\end{array}$ & $-40 /-15[5]$ & $\begin{array}{l}\text { GLP-1 }(\leftrightarrow) \uparrow, \operatorname{PYY}(\leftrightarrow) \uparrow, \operatorname{GIP}(\leftrightarrow) \leftrightarrow, \\
\text { glucagon }(\leftrightarrow) \leftrightarrow[6]\end{array}$ \\
\hline Inhoe [89] & -17 & 0 & no & NR & NR \\
\hline Kaplan $[23,111]$ & -17 & -20 to 30 & yes & -16.8 & ghrelin $\downarrow$ \\
\hline Le Roux $[17,18,75,100]$ & -8 to 11 & -10 to 15 & yes & -15 to 20 & GLP-1 $(\uparrow) \uparrow[12] ; \mathrm{PYY}(\uparrow) \uparrow[12], \mathrm{GLP}-2(\uparrow)[14]$ \\
\hline Li [112] & NR & NR & NR & NR & NR \\
\hline $\mathrm{Xu}[90,94,117,118]$ & -18 & -9 & no & -25 & leptin $\downarrow[30]$ \\
\hline Meguid $[19,21,73,113,114]$ & $\begin{array}{l}-18 \\
-25\end{array}$ & $\begin{array}{l}-25 \\
-34(-14)\end{array}$ & $\begin{array}{l}\text { yes } \\
\text { yes }\end{array}$ & $-23(0)$ & $\begin{array}{l}\text { NR } \\
\text { ghrelin } \leftrightarrow, \text { CCK } \uparrow(3) \leftrightarrow(13), \text { PYY } \uparrow, \text { leptin } \downarrow \\
\text { GLP-1 } \leftrightarrow[20], \\
\text { adiponectin } \downarrow(\leftrightarrow)[17,18,20]\end{array}$ \\
\hline Murr $[115,116]$ & NR & NR & NR & NR & NR \\
\hline Taqui [63] & -21.6 & - & - & - & $\mathrm{PYY} \uparrow, \mathrm{GLP}-2 \uparrow$ \\
\hline Tichansky $[34,108]$ & $\begin{array}{l}-20 \\
-15\end{array}$ & $\begin{array}{l}-11 \\
-5\end{array}$ & $\begin{array}{l}\text { no } \\
\text { no }\end{array}$ & $\begin{array}{l}\downarrow \\
\mathrm{NR}\end{array}$ & $\begin{array}{l}-[25] \\
-[26]\end{array}$ \\
\hline Wang [33] & NR & $\uparrow$ & no & NR & $\operatorname{ghrelin}(\downarrow) \downarrow$; leptin $\downarrow$ \\
\hline Young [119] & 8 & NR & NR & -30 & NR \\
\hline
\end{tabular}

GLP-1/2 = Glucagon-like peptide 1/2; PYY = peptide YY; GIP = gastric inhibitory polypeptide; CCK = cholecystokinin; NR = not reported.

\section{Postoperative Changes in Gut Morphometry}

Hypertrophy of the small bowel has only been described after biliopancreatic diversion in humans [74], but not after gastric bypass. In contrast, a considerable mucosal and muscle hypertrophy of the alimentary limb and the common channel has been described in rats $[18,63,75,76]$. This observation seems to be independent of the alimentary limb $(10-50 \mathrm{~cm})$ and common channel $(20-50 \mathrm{~cm})$ length $[18,63,75,76]$. These findings are in accordance with elevated levels of GLP-2 after gastric bypass, which has been shown to promote cellular division of ileal mucosal cells and to inhibit apoptosis $[63,75]$. Thus, the epithelial cell proliferation described endows the gut with the capacity to restore the absorptive surface area, thereby limiting malabsorption [75]. The gut hypertrophy may also partly explain the increased energy expenditure after gastric bypass in rats $[18,23]$.

\section{Vagus}

The vagal nerve plays an important role in the regulation of food intake and body weight [77]. Chronic vagal nerve stimulation decreases sweet craving, food intake, and body weight gain in minipigs [78]. Vagal afferents transmit information from stretch and chemoreceptors which are activated by the presence of nutrients in the stomach and the intestine, respectively [79]. Furthermore, gut hormone signaling and the vagal nerve are closely intertwined as the release of gut hormones as well as their effects is influenced by vagal signals [80]. Thus, serum levels of pancreatic polypeptide have been used to measure vagal efferent function [81, 82]. The blockade of vagal impulses reduces ghrelin levels in humans [83], and exogenous ghrelin administration to vagotomized patients does not stimulate food intake [84]. Satiety-inducing gut hormones such as PYY and GLP-1 may also act via afferent vagal fibers [77]. Vagal afferents are relayed to central nervous system structures, including the nucleus tractus solitarii which is known to be important in mediating food intake [85]. Additionally, vagal efferent signals have been shown to regulate the motility of the gastrointestinal tract directly through cholinergic signaling [86]. To date, the relevance of the vagal nerve for body weight after gastric bypass is incompletely understood [71, 77, 87]. We demonstrated previously that preserving vagal fibers of the dorsal vagal trunk during the gastric bypass operation may lead to greater and more sustained body weight loss in rats [17]. This is consistent with previous 


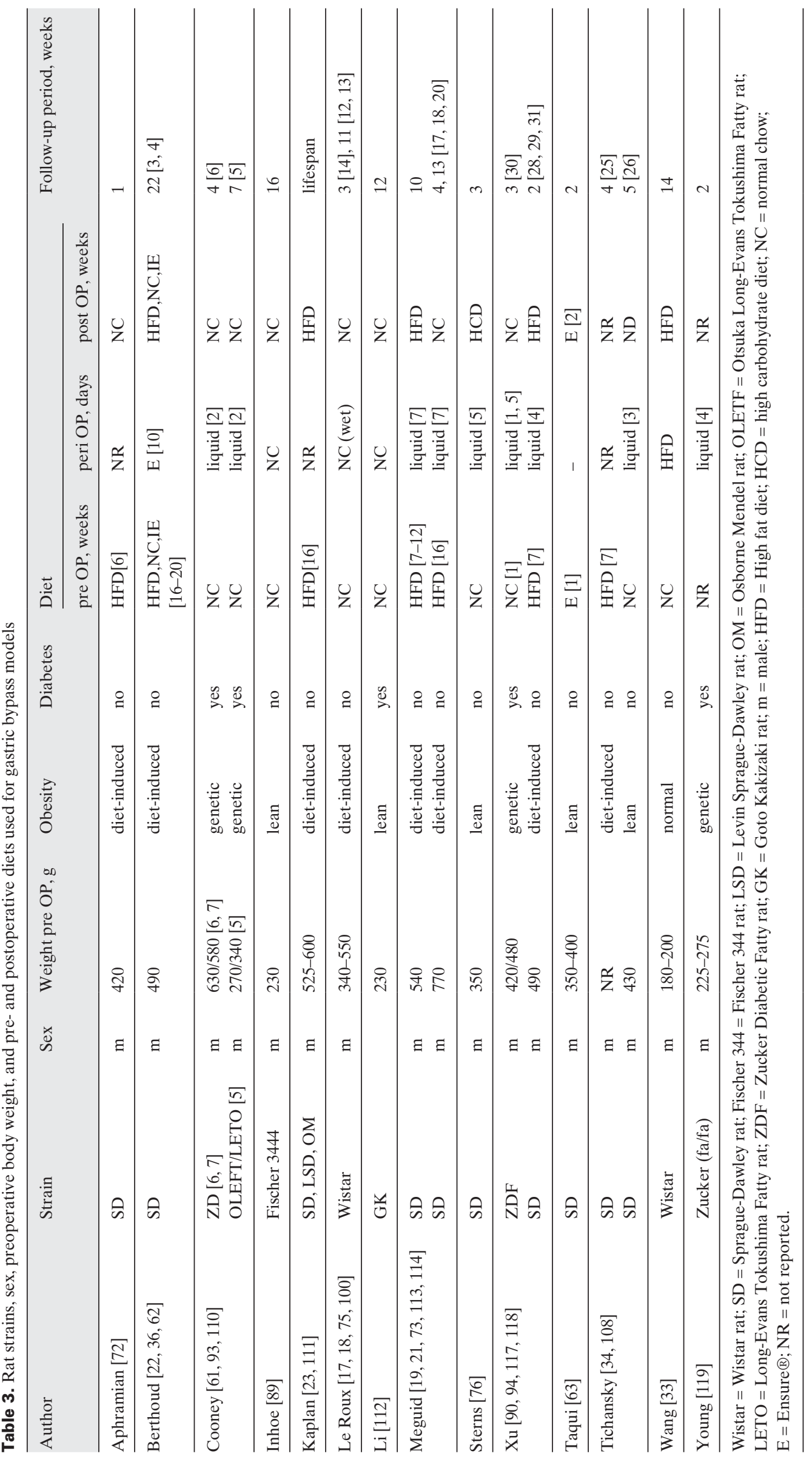


reports showing that the ablation of the vagal-brainstem-hypothalamic pathway attenuates the inhibitory effects of PYY and GLP-1 on food intake [88]. In contrast, Wang and Liu [33] observed greater initial weight loss after total vagotomy in gastric bypass rats, but the weight loss difference was not sustained in the long term.

\section{Mortality Rate}

Mortality rates after gastric bypass are rarely reported but seem to range from 0 to $35 \%$ (table 1 ). Reported mortality was due to anastomotic leakage or stenosis [17, 21, 76, 89], bleeding after transecting of the stomach [21,76], compromising of mesenteric vessels due to intussuseption or internal hernia [17, 90], wound dehiscence[90], intraoperative death or narcotic accident [21, 22], and persistent weight loss leading to compromised animal welfare [76]. Differences may be due to surgical learning curves. Technical aspects such as type of anastomosis (end-to-side vs. side-to-side), suturing (interrupted vs. continuous), using a stapler device, pouch size, preservation of the vagal nerve, operation time, antibiotics, type of general anesthesia and analgesia do not predict the surgical outcome. Furthermore, it can be hypothesized that the perioperative diet may also impact on the mortality rate. As a result, some authors prefer to give liquid diets to the animals postoperatively (table 3), although no data has been presented to suggest that this improves immediate postoperative mortality.

\section{Strains}

Apart from the differences in operative techniques, several different strains of rats have been used. Their specific characteristics haven been published elsewhere (Wistar rat [91], Sprague-Dawley (SD) rat [91], Fischer 344 rat [89, 92, 93], Levin Sprague-Dawley (LSD) rat [23], Osborne Mendel (OM) rat [23], Otsuka Long-Evans Tokushima Fatty (OLETF) [91, 93] rat, Long-Evans Tokushima Fatty (LETO) rat, Zucker Diabetic Fatty (ZDF) rat [90, 91, 94], and Goto Kakizaki (GK) rat [91]). The applicability of the different available rat strains in the field of bariatric surgery research has been discussed in a separate review by Mistry et al. [91]. It is reasonable to assume that the choice of rat strain may directly impact on the metabolic findings. Moreover, each rat strain may have a very specific and therefore different capacity to cope with surgical trauma.

\section{Sex}

Approximately $80 \%$ of patients undergoing bariatric surgery are female [4]. In contrast, all available rat studies being performed so far have used male animals exclusively (table 3 ). This gender bias may have practical reasons as male rats are known to gain weight faster than females [95, 96]. Another general advantage is the absence of hormone alterations during the estrous cycle. Female rats have an estrous cycle of 4 days, which is therefore likely to affect food intake and potentially the metabolic outcome [95, 97, 98].

\section{Diet and Age}

Most of the available rat studies have been carried out on obese animals. Some strains used are genetically obese (e.g. the ZDF rats) and were fed normal chow (table 3). In other studies, obesity was induced by feeding high fat diets (table 3 ) aiming to induce a metabolic syndrome similar to that found in humans [99]. However, there was variability in both the composition of the high fat diets and in the time period in which they were consumed (ranging from 6 to 20 weeks). Normal chow has also been used to induce obesity, although this approach takes longer $[8,17,18,75,100]$. The age of the animals may also impact on metabolic rate and other more subtle physiological parameters [101]. Postoperatively, the rats were fed different diets (table 3 ). Some groups changed from a high fat preoperative diet to a low fat diet after surgery. Thus, the change in diet itself can also affect body weight.

\section{Food Intake and Body Weight}

Gastric bypass in humans induces and sustains a body weight loss of approximately 15-30\% [4]. Most of the body weight loss occurs during the first postoperative year [102] partly due to reduced food intake, altered food preference, and increased energy expenditure [9-11]. Physiological weight regain occurs after gastric bypass, but an average weight loss of $25 \%$ has been reported at 15 years after the operation [102]. Most gastric bypass rat models also induce a significant reduction in food intake and body weight (table 2). Some models are characterized by maintenance of the low body weight $[17,18]$ while others display a constant weight regain paralleling the body weight of sham-operated controls shortly after gastric bypass [19]. However, body weight loss is usually accompanied by a greater reduction of subcutaneous and visceral fat mass compared to the lean body mass loss $[18,19$, $36,61,90]$. Thus, animals display similar changes to humans in terms of body composition after gastric bypass-induced weight loss.

Immediate delivery of food to the small bowel may be more important than the size of the pouch to explain the observed reduced food intake [103]. Prompt pouch emptying seems to predict body weight loss after gastric bypass [104], but delayed gastric empting and a prolonged intestinal transit time has also been reported after gastric bypass [23, 73]. As mentioned above, the different components of the bypass operation lead to alterations of a complex enteroendocrine and neuroendocrine response [85], and reduction of food intake might be related to postoperatively increased enterohormones like PYY or GLP-1 inducing satiety after gastric bypass. In this respect, le Roux et al. [9] showed that postprandial PYY and GLP-1 responses were attenuated in patients with poor weight loss after gastric bypass, which was associated with increased appetite compared to patients with good weight loss. Meguid et al. [105] showed that postoperative weight regain relates to a decreased PYY/leptin ratio in rats. 
The absence of compensatory increased appetite after gastric bypass-induced weight loss has been intriguing as voluntary weight loss usually leads to weight regain through increased appetite [106]. Food preference changes to low-calorie dense foods in humans [107] and rodents after gastric bypass $[22,93,108]$ also play a role. Chronic caloric deprivation is usually accompanied by a decrease in resting energy expenditure as the organism attempts to conserve energy to enhance survival [106]. Interestingly, energy expenditure has been shown to increase in humans $[10,109]$ and rodents $[18$, 23] after gastric bypass.

\section{Conclusion}

There is a great variety of gastric bypass rat models differing in pouch size, limb length, and preservation of the vagal nerve. Furthermore, gastric bypass has been performed in different rat strains at different ages on different diets. Nevertheless, the human phenotype in terms of weight loss and food intake has been successfully mimicked by most rat gastric bypass models. Several components acting in concert lead to the observed physiological changes after gastric by- pass. The relative contribution of these components and their interaction is not yet known. The variety in available rat gastric bypass models makes it difficult to identify specific physiological mechanisms involved in gastric bypass. It seems plausible that the different rat models of gastric bypass achieved the same phenotype of weight loss by combining very different components of what is perceived to constitute a gastric bypass. Thus, there is an emerging need for standardization of the procedure to achieve consistent and comparable data, but thus far there is no evidence that any particular model is superior.

\section{Acknowledgements}

F.S. was supported by the Deutsche Forschungsgemeinschaft (DFG). We would like to thank Mohammed Hakir for reading the manuscript and Anne Schmutzler for drawing the figures.

\section{Disclosure Statement}

The authors have no conflict of interest to disclose.

\section{References}

$\checkmark 1$ Adams TD, Gress RE, Smith SC, Halverson RC, Simper SC, Rosamond WD, Lamonte MJ, Stroup AM, Hunt SC: Long-term mortality after gastric bypass surgery. N Engl J Med 2007;357:753-761.

2 Sjostrom L, Lindroos AK, Peltonen M, Torgerson J, Bouchard C, Carlsson B, Dahlgren S, Larsson B, Narbro K, Sjostrom CD, Sullivan M, Wedel H: Lifestyle, diabetes, and cardiovascular risk factors 10 years after bariatric surgery. N Engl J Med 2004;351:2683-2693.

3 Buchwald H, Oien DM: Metabolic/bariatric surgery worldwide 2008. Obes Surg 2009;19:1605-1611.

4 Sjostrom L, Narbro K, Sjostrom CD, Karason K, Larsson B, Wedel H, Lystig T, Sullivan M, Bouchard C, Carlsson B, Bengtsson C, Dahlgren S Gummesson A, Jacobson P, Karlsson J, Lindroos AK, Lonroth H, Naslund I, Olbers T, Stenlof K, Torgerson J, Agren G, Carlsson LM: Effects of bariatric surgery on mortality in Swedish obese subjects. N Engl J Med 2007;357:741-752.

5 Mason EE, Printen KJ, Lewis JW, Scott DH, Blommers TJ: Gastric bypass criteria for effectiveness. Int J Obes 1981;5:405-411.

6 Ashrafian H, le Roux CW: Metabolic surgery and gut hormones - a review of bariatric entero-humoral modulation. Physiol Behav 2009;97:620-631.

7 Ashrafian H, Athanasiou T, Li JV, Bueter M, Ahmed K, Nagpal K, Holmes E, Darzi A, Bloom SR: Diabetes resolution and hyperinsulinaemia after metabolic Roux-en-Y gastric bypass. Obes Rev 2010; doi: 10.1111/j.1467-789X.2010.00802.x..

$>8$ Le Roux CW, Aylwin SJ, Batterham RL, Borg CM, Coyle F, Prasad V, Shurey S, Ghatei MA, Patel AG, Bloom SR: Gut hormone profiles following bariatric surgery favor an anorectic state, facilitate weight loss, and improve metabolic parameters. Ann Surg 2006;243:108-114.
9 Le Roux CW, Welbourn R, Werling M, Osborne A, Kokkinos A, Laurenius A, Lonroth H, Fandriks L, Ghatei MA, Bloom SR, Olbers T: Gut hormones as mediators of appetite and weight loss after Roux-en-Y gastric bypass. Ann Surg 2007;246: 780-785.

10 Olbers T, Bjorkman S, Lindroos A, Maleckas A, Lonn L, Sjostrom L, Lonroth H: Body composition, dietary intake, and energy expenditure after laparoscopic Roux-en-Y gastric bypass and laparoscopic vertical banded gastroplasty: a randomized clinical trial. Ann Surg 2006;244:715-722.

11 Carrasco F, Papapietro K, Csendes A, Salazar G, Echenique C, Lisboa C, Diaz E, Rojas J: Changes in resting energy expenditure and body composition after weight loss following Roux-en-Y gastric bypass. Obes Surg 2007;17:608-616.

12 Sugerman HJ, Starkey JV, Birkenhauer R: A randomized prospective trial of gastric bypass versus vertical banded gastroplasty for morbid obesity and their effects on sweets versus non-sweets eaters. Ann Surg 1987;205:613-624.

13 Thomas JR, Marcus E: High and low fat food selection with reported frequency intolerance following Roux-en-Y gastric bypass. Obes Surg 2008;18: 282-287.

14 Kashyap SR, Daud S, Kelly KR, Gastaldelli A, Win H, Brethauer S, Kirwan JP, Schauer PR: Acute effects of gastric bypass versus gastric restrictive surgery on beta-cell function and insulinotropic hormones in severely obese patients with type 2 diabetes. Int J Obes (Lond) 2010;34:462471.

15 Lin E, Davis SS, Srinivasan J, Sweeney JF, Ziegler TR, Phillips L, Gletsu-Miller N: Dual mechanism for type-2 diabetes resolution after Roux-en-Y gastric bypass. Am Surg 2009;75:498-502.
16 Pournaras DJ, Osborne A, Hawkins SC, Vincent RP, Mahon D, Ewings P, Ghatei MA, Bloom SR, Welbourn R, le Roux CW: Remission of type 2 diabetes after gastric bypass and banding: mechanisms and 2 year outcomes. Ann Surg 2010;252:966-971.

17 Bueter M, Lowenstein C, Ashrafian H, Hillebrand J, Bloom SR, Olbers T, Lutz T, le Roux CW: Vagal sparing surgical technique but not stoma size affects body weight loss in rodent model of gastric bypass. Obes Surg 2010;20:616-622.

18 Bueter M, Lowenstein C, Olbers T, Wang M, Cluny NL, Bloom SR, Sharkey KA, Lutz TA, le Roux CW: Gastric bypass increases energy expenditure in rats. Gastroenterology 2010;138:1845-1853.

19 Guijarro A, Suzuki S, Chen C, Kirchner H, Middleton FA, Nadtochiy S, Brookes PS, Niijima A, Inui A, Meguid MM: Characterization of weight loss and weight regain mechanisms after Rouxen-Y gastric bypass in rats. Am J Physiol Regul Integr Comp Physiol 2007;293:R1474-R1489.

20 Kirchner H, Guijarro A, Meguid MM: Is a model useful in exploring the catabolic mechanisms of weight loss after gastric bypass in humans? Curr Opin Clin Nutr Metab Care 2007;10:463-474

21 Meguid MM, Ramos EJ, Suzuki S, Xu Y, George ZM, Das UN, Hughes K, Quinn R, Chen C, Marx W, Cunningham PR: A surgical rat model of human Roux-en-Y gastric bypass. J Gastrointest Surg 2004; 8:621-630.

22 Shin AC, Zheng H, Pistell PJ, Berthoud HR: Roux-en-Y gastric bypass surgery changes food reward in rats. Int J Obes (Lond) 2010; doi:10.1038/ ijo.2010.174.

23 Stylopoulos N, Hoppin AG, Kaplan LM: Roux-en$\mathrm{Y}$ gastric bypass enhances energy expenditure and extends lifespan in diet-induced obese rats. Obesity (Silver Spring) 2009;17:1839-1847. 
24 Chandarana K, Gelegen C, Karra E, Choudhury AI, Drew ME, Fauveau V, Viollet B, Andreelli F, Withers DJ, Batterham RL: Diet and gastrointestinal bypass-induced weight loss: the roles of ghrelin and peptide YY. Diabetes 2011;60:810-818.

25 Lan Z, Zassoko R, Liu W, Garcia B, Sun H, Wang $\mathrm{R}$, Wang H: Development of techniques for gastrojejunal bypass surgery in obese mice. Microsurgery 2010;30:289-295.

26 Liu W, Zassoko R, Mele T, Luke P, Sun H, Liu W, Garcia B, Jiang J, Wang H: Establishment of duodenojejunal bypass surgery in mice: a model designed for diabetic research. Microsurgery 2008;28: 197-202.

27 Troy S, Soty M, Ribeiro L, Laval L, Migrenne S, Fioramonti X, Pillot B, Fauveau V, Aubert R, Viollet B, Foretz M, Leclerc J, Duchampt A, Zitoun C, Thorens B, Magnan C, Mithieux G, Andreelli F: Intestinal gluconeogenesis is a key factor for early metabolic changes after gastric bypass but not after gastric lap-band in mice. Cell Metab 2008;8:201-211.

28 Mason EE, Ito C: Gastric bypass in obesity. Surg Clin North Am 1967:47:1345-1351.

-29 Nishie A, Brown B, Barloon T, Kuehn D, Samuel I: Comparison of size of proximal gastric pouch and short-term weight loss following routine upper gastrointestinal contrast study after laparoscopic Rouxen-Y gastric bypass. Obes Surg 2007;17:1183-1188.

-30 O'Connor EA, Carlin AM: Lack of correlation between variation in small-volume gastric pouch size and weight loss after laparoscopic Roux-en-Y gastric bypass. Surg Obes Relat Dis 2008;4:399-403.

31 Roberts K, Duffy A, Kaufman J, Burrell M, Dziura J, Bell R: Size matters: gastric pouch size correlates with weight loss after laparoscopic Roux-en-Y gastric bypass. Surg Endosc 2007;21:1397-1402.

-32 Stearns AT, Balakrishnan A, Rhoads DB, Ashley SW, Tavakkolizadeh A: Diurnal expression of the rat intestinal sodium-glucose cotransporter 1 (SGLT1) is independent of local luminal factors. Surgery 2009;145:294-302.

33 Wang Y, Liu J: Combination of bypassing stomach and vagus dissection in high-fat diet-induced obese rats-a long-term investigation. Obes Surg 2010;20: 375-379.

\34 Tichansky DS, Boughter JD Jr, Harper J, Glatt AR, Madan AK: Gastric bypass surgery in rats produces weight loss modeling after human gastric bypass. Obes Surg 2008;18:1246-1250.

35 Furnes MW, Tommeras K, Arum CJ, Zhao CM, Chen D: Gastric bypass surgery causes body weight loss without reducing food intake in rats. Obes Surg 2008;18:415-422.

\$36 Zheng H, Shin AC, Lenard NR, Townsend RL, Patterson LM, Sigalet DL, Berthoud HR: Meal patterns, satiety, and food choice in a rat model of Roux-en-Y gastric bypass surgery. Am J Physiol Regul Integr Comp Physiol 2009;297:R1273-R1282.

- 37 Christou NV, Look D, Maclean LD: Weight gain after short- and long-limb gastric bypass in patients followed for longer than 10 years. Ann Surg 2006; 244:734-740.

38 Gleysteen JJ: Five-year outcome with gastric bypass: Roux limb length makes a difference. Surg Obes Relat Dis 2009;5:242-247.

-39 Lee S, Sahagian KG, Schriver JP: Relationship between varying Roux limb lengths and weight loss in gastric bypass. Curr Surg 2006;63:259-263.

40 Choban PS, Flancbaum L: The effect of Roux limb lengths on outcome after Roux-en-Y gastric bypass: a prospective, randomized clinical trial. Obes Surg 2002;12:540-545.
41 Feng JJ, Gagner M, Pomp A, Korgaonkar NM, Jacob BP, Chu CA, Voellinger DC, Quinn T, Herron DM, Inabnet WB: Effect of standard vs. extended Roux limb length on weight loss outcomes after laparoscopic Roux-en-Y gastric bypass. Surg Endosc 2003;17:1055-1060.

42 Inabnet WB, Quinn T, Gagner M, Urban M, Pomp A: Laparoscopic Roux-en-Y gastric bypass in patients with BMI <50: a prospective randomized trial comparing short and long limb lengths. Obes Surg 2005;15:51-57.

43 Muller MK, Rader S, Wildi S, Hauser R, Clavien PA, Weber M: Long-term follow-up of proximal versus distal laparoscopic gastric bypass for morbid obesity. Br J Surg 2008;95:1375-1379.

44 Pinheiro JS, Schiavon CA, Pereira PB, Correa JL, Noujaim P, Cohen R: Long-long limb Roux-en-Y gastric bypass is more efficacious in treatment of type 2 diabetes and lipid disorders in super-obese patients. Surg Obes Relat Dis 2008;4:521-525.

45 Odstrcil EA, Martinez JG, Santa Ana CA, Xue B, Schneider RE, Steffer KJ, Porter JL, Asplin J, Kuhn JA, Fordtran JS: The contribution of malabsorption to the reduction in net energy absorption after long-limb Roux-en-Y gastric bypass. Am J Clin Nutr 2010;92:704-713.

46 Scopinaro N, Gianetta E, Pandolfo N, Anfossi A, Berretti B, Bachi V: Bilio-pancreatic bypass. Proposal and preliminary experimental study of a new type of operation for the functional surgical treatment of obesity (in Italian). Minerva Chir 1976;31: 560-566.

47 Glicksman C, Pournaras DJ, Wright M, Roberts R, Mahon D, Welbourn R, Sherwood R, AlaghbandZadeh J, le Roux CW: Postprandial plasma bile acid responses in normal weight and obese subjects. Ann Clin Biochem 2010;47:482-484.

48 Knop FK: Bile-induced secretion of glucagon-like peptide-1: pathophysiological implications in type 2 diabetes? Am J Physiol Endocrinol Metab 2010; 299:E10-E13.

49 Nakatani H, Kasama K, Oshiro T, Watanabe M, Hirose $\mathrm{H}$, Itoh $\mathrm{H}$ : Serum bile acid along with plasma incretins and serum high-molecular weight adiponectin levels are increased after bariatric surgery. Metabolism 2009;58:1400-1407.

50 Makishima M, Okamoto AY, Repa JJ, Tu H, Learned RM, Luk A, Hull MV, Lustig KD, Mangelsdorf DJ, Shan B: Identification of a nuclear receptor for bile acids. Science 1999;284:1362-1365.

51 Buchwald H, Estok R, Fahrbach K, Banel D, Jensen MD, Pories WJ, Bantle JP, Sledge I: Weight and type 2 diabetes after bariatric surgery: systematic review and meta-analysis. Am J Med 2009;122: 248-256.

52 Cummings DE, Weigle DS, Frayo RS, Breen PA, Ma MK, Dellinger EP, Purnell JQ: Plasma ghrelin levels after diet-induced weight loss or gastric bypass surgery. N Engl J Med 2002;346:1623-1630.

53 Pournaras DJ, le Roux CW: Obesity, gut hormones, and bariatric surgery. World J Surg 2009;33: 1983-1988.

54 Adrian TE, Ballantyne GH, Longo WE, Bilchik AJ, Graham S, Basson MD, Tierney RP, Modlin IM: Deoxycholate is an important releaser of peptide YY and enteroglucagon from the human colon. Gut 1993;34:1219-1224.

55 Schwartz MW, Woods SC, Porte D Jr, Seeley RJ, Baskin DG: Central nervous system control of food intake. Nature 2000;404:661-671.

56 Schwartz MW, Morton GJ: Obesity: keeping hunger at bay. Nature 2002;418:595-597.
57 Batterham RL, Cowley MA, Small CJ, Herzog H, Cohen MA, Dakin CL, Wren AM, Brynes AE, Low MJ, Ghatei MA, Cone RD, Bloom SR: Gut hormone PYY(3-36) physiologically inhibits food intake. Nature 2002;418:650-654

58 Batterham RL, Cohen MA, Ellis SM, le Roux CW Withers DJ, Frost GS, Ghatei MA, Bloom SR: Inhibition of food intake in obese subjects by peptide YY3-36. N Engl J Med 2003;349:941-948.

59 Kreymann B, Williams G, Ghatei MA, Bloom SR: Glucagon-like peptide-1 7-36: a physiological incretin in man. Lancet 1987;2:1300-1304.

60 Farilla L, Bulotta A, Hirshberg B, Li CS, Khoury N, Noushmehr H, Bertolotto C, Di MU, Harlan DM, Perfetti R: Glucagon-like peptide 1 inhibits cell apoptosis and improves glucose responsiveness of freshly isolated human islets. Endocrinology 2003;144:5149-5158.

61 Meirelles K, Ahmed T, Culnan DM, Lynch CJ Lang $\mathrm{CH}$, Cooney RN: Mechanisms of glucose homeostasis after Roux-en-Y gastric bypass surgery in the obese, insulin-resistant Zucker rat. Ann Surg 2009;249:277-285.

62 Shin AC, Zheng H, Townsend RL, Sigalet DL, Berthoud HR: Meal-induced hormone responses in a rat model of Roux-en-Y gastric bypass surgery. Endocrinology 2010;151:1588-1597.

63 Taqi E, Wallace LE, de HE, Chelikani PK, Zheng H, Berthoud HR, Holst JJ, Sigalet DL: The influence of nutrients, biliary-pancreatic secretions, and systemic trophic hormones on intestinal adaptation in a Roux-en-Y bypass model. J Pediatr Surg 2010; 45:987-995.

64 Wren AM, Small CJ, Abbott CR, Dhillo WS, Seal LJ, Cohen MA, Batterham RL, Taheri S, Stanley SA, Ghatei MA, Bloom SR: Ghrelin causes hyperphagia and obesity in rats. Diabetes 2001;50:25402547.

65 Wren AM, Seal LJ, Cohen MA, Brynes AE, Frost GS, Murphy KG, Dhillo WS, Ghatei MA, Bloom SR: Ghrelin enhances appetite and increases food intake in humans. J Clin Endocrinol Metab 2001; 86:5992.

66 Kojima M, Hosoda H, Date Y, Nakazato M, Matsuo $\mathrm{H}$, Kangawa $\mathrm{K}$ : Ghrelin is a growth-hormonereleasing acylated peptide from stomach. Nature 1999:402:656-660.

67 Cummings DE, Purnell JQ, Frayo RS, Schmidova $\mathrm{K}$, Wisse BE, Weigle DS: A preprandial rise in plasma ghrelin levels suggests a role in meal initiation in humans. Diabetes 2001;50:1714-1719.

68 Callahan HS, Cummings DE, Pepe MS, Breen PA Matthys CC, Weigle DS: Postprandial suppression of plasma ghrelin level is proportional to ingested caloric load but does not predict intermeal interval in humans. J Clin Endocrinol Metab 2004;89:13191324.

69 Le Roux CW, Patterson M, Vincent RP, Hunt C, Ghatei MA, Bloom SR: Postprandial plasma ghrelin is suppressed proportional to meal calorie content in normal-weight but not obese subjects. J Clin Endocrinol Metab 2005;90:1068-1071.

70 Holdstock C, Engstrom BE, Ohrvall M, Lind L, Sundbom M, Karlsson FA: Ghrelin and adipose tissue regulatory peptides: effect of gastric bypass surgery in obese humans. J Clin Endocrinol Metab 2003;88:3177-3183.

71 Sundbom M, Holdstock C, Engstrom BE, Karlsson FA: Early changes in ghrelin following Roux-en-Y gastric bypass: influence of vagal nerve functionality? Obes Surg 2007;17:304-310. 
72 Aprahamian CJ, Tekant G, Chen M, Yagmurlu A, Yang YK, Loux T, Harmon CM: A rat model of childhood diet-induced obesity: Roux-en-Y gastric bypass induced changes in metabolic parameters and gastric peptide ghrelin. Pediatr Surg Int 2007; 23:653-657.

73 Suzuki S, Ramos EJ, Goncalves CG, Chen C, Meguid MM: Changes in GI hormones and their effect on gastric emptying and transit times after Rouxen-Y gastric bypass in rat model. Surgery $2005 ; 138$ : 283-290.

74 Stock-Damge C, Aprahamian M, Raul F, Marescaux J, Scopinaro N: Small-intestinal and colonic changes after biliopancreatic bypass for morbid obesity. Scand J Gastroenterol 1986;21:1115-1123.

75 Le Roux CW, Borg C, Wallis K, Vincent RP, Bueter M, Goodlad R, Ghatei MA, Patel A, Bloom SR, Aylwin SJ: Gut hypertrophy after gastric bypass is associated with increased glucagon-like peptide 2 and intestinal crypt cell proliferation. Ann Surg 2010;252:50-56.

76 Stearns AT, Balakrishnan A, Tavakkolizadeh A: Impact of Roux-en-Y gastric bypass surgery on rat intestinal glucose transport. Am J Physiol Gastrointest Liver Physiol 2009;297:G950-G957.

77 Berthoud HR: The vagus nerve, food intake and obesity. Regul Pept 2008;149:15-25.

78 Val-Laillet D, Biraben A, Randuineau G, Malbert $\mathrm{CH}$ : Chronic vagus nerve stimulation decreased weight gain, food consumption and sweet craving in adult obese minipigs. Appetite 2010;55:245-252.

79 Sobocki J, Fourtanier G, Estany J, Otal P: Does vagal nerve stimulation affect body composition and metabolism? Experimental study of a new potential technique in bariatric surgery. Surgery 2006;139:209-216.

80 Date Y, Murakami N, Toshinai K, Matsukura S, Niijima A, Matsuo H, Kangawa K, Nakazato M: The role of the gastric afferent vagal nerve in ghrelin-induced feeding and growth hormone secretion in rats. Gastroenterology 2002;123:1120-1128.

81 Feldman M, Richardson CT: Role of thought, sight, smell, and taste of food in the cephalic phase of gastric acid secretion in humans. Gastroenterology 1986;90:428-433.

82 Greydanus MP, Vassallo M, Camilleri M, Nelson DK, Hanson RB, Thomforde GM: Neurohormonal factors in functional dyspepsia: insights on pathophysiological mechanisms. Gastroenterology 1991; 100:1311-1318.

83 Broglio F, Gottero C, Van KP, Prodam F, Destefanis S, Benso A, Gauna C, Hofland L, Arvat E, van der Lely AJ, Ghigo E: Acetylcholine regulates ghrelin secretion in humans. J Clin Endocrinol Metab 2004;89:2429-2433.

84 Le Roux CW, Neary NM, Halsey TJ, Small CJ, Martinez-Isla AM, Ghatei MA, Theodorou NA, Bloom SR: Ghrelin does not stimulate food intake in patients with surgical procedures involving vagotomy. J Clin Endocrinol Metab 2005;90:4521-4524.

85 Morton GJ, Cummings DE, Baskin DG, Barsh GS, Schwartz MW: Central nervous system control of food intake and body weight. Nature 2006;443:289295.

86 Konturek SJ, Kwiecien N, Obtulowicz W, Thor P, Konturek JW, Popiela T, Oleksy J: Vagal cholinergic control of gastric alkaline secretion in normal subjects and duodenal ulcer patients. Gut 1987;28: 739-744.
87 Perathoner A, Weiss H, Santner W, Brandacher G, Laimer E, Holler E, Aigner F, Klaus A: Vagal nerve dissection during pouch formation in laparoscopic Roux-Y-gastric bypass for technical simplification: does it matter? Obes Surg 2009;19:412-417.

88 Abbott CR, Monteiro M, Small CJ, Sajedi A, Smith KL, Parkinson JR, Ghatei MA, Bloom SR: The inhibitory effects of peripheral administration of peptide YY(3-36) and glucagon-like peptide-1 on food intake are attenuated by ablation of the vagal-brainstem-hypothalamic pathway. Brain Res 2005;1044:127-131

89 Inoue H, Rubino F, Shimada Y, Lindner V, Inoue M, Riegel P, Marescaux J: Risk of gastric cancer after Roux-en-Y gastric bypass. Arch Surg 2007; 142:947-953.

90 Xu Y, Ohinata K, Meguid MM, Marx W, Tada T, Chen C, Quinn R, Inui A: Gastric bypass model in the obese rat to study metabolic mechanisms of weight loss. J Surg Res 2002;107:56-63.

91 Mistry SB, Omana JJ, Kini S: Rat models for bariatric surgery and surgery for type 2 diabetes mellitus. Obes Surg 2009;19:655-660.

92 Feuers RJ, Duffy PH, Leakey JA, Turturro A, Mittelstaedt RA, Hart RW: Effect of chronic caloric restriction on hepatic enzymes of intermediary metabolism in the male Fischer 344 rat. Mech Ageing Dev 1989;48:179-189.

93 Hajnal A, Kovacs P, Ahmed T, Meirelles K, Lynch CJ, Cooney RN: Gastric bypass surgery alters behavioral and neural taste functions for sweet taste in obese rats. Am J Physiol Gastrointest Liver Physiol 2010;299:G967-G979.

94 Xu Y, Ramos EJ, Middleton F, Romanova I, Quinn R, Chen C, Das U, Inui A, Meguid MM: Gene expression profiles post Roux-en-Y gastric bypass. Surgery 2004;136:246-252.

95 Meguid MM: In the matter of sex...sex matters in medical-scientific research. Nutrition 2008;24:767768.

96 Riesenfeld A: Constitution and body proportions in different strains of rats. A study of race formation in breeding isolates. Acta Anat (Basel) 1976; 94:169-183.

97 Czaja JA: Sex differences in the activational effects of gonadal hormones on food intake and body weight. Physiol Behav 1984;33:553-558.

98 Gentry RT, Wade GN: Sex differences in sensitivity of food intake, body weight, and runningwheel activity to ovarian steroids in rats. J Comp Physiol Psychol 1976;90:747-754.

99 Akiyama T, Tachibana I, Shirohara H, Watanabe N, Otsuki M: High-fat hypercaloric diet induces obesity, glucose intolerance and hyperlipidemia in normal adult male Wistar rat. Diabetes Res Clin Pract 1996;31:27-35.

100 Bueter M, Ashrafian H, Frankel AH, Tam FW, Unwin RJ, le Roux CW: Sodium and water handling after gastric bypass surgery in a rat model. Surg Obes Relat Dis 2010.

101 Quinn R: Comparing rat's to human's age: how old is my rat in people years? Nutrition 2005;21: 775-777.

102 Sjostrom L: Bariatric surgery and reduction in morbidity and mortality: experiences from the SOS study. Int J Obes (Lond) 2008;32(suppl 7): S93-S97.

103 Bjorklund P, Laurenius A, Een E, Olbers T, Lonroth H, Fandriks L: Is the Roux limb a determinant for meal size after gastric bypass surgery? Obes Surg 2010;20:1408-1414.
104 Akkary E, Sidani S, Boonsiri J, Yu S, Dziura J, Duffy AJ, Bell RL: The paradox of the pouch: prompt emptying predicts improved weight loss after laparoscopic Roux-Y gastric bypass. Surg Endosc 2009;23:790-794.

105 Meguid MM, Glade MJ, Middleton FA: Weight regain after Roux-en-Y: a significant $20 \%$ complication related to PYY. Nutrition 2008;24:832-842.

106 Schwartz MW, Woods SC, Seeley RJ, Barsh GS, Baskin DG, Leibel RL: Is the energy homeostasis system inherently biased toward weight gain? Diabetes 2003;52:232-238.

107 Miras AD, le Roux CW: Bariatric surgery and taste: novel mechanisms of weight loss. Curr Opin Gastroenterol 2010;26:140-145.

108 Tichansky DS, Rebecca GA, Madan AK, Harper J, Tokita K, Boughter JD: Decrease in sweet taste in rats after gastric bypass surgery. Surg Endosc 2010.

109 Flancbaum L, Choban PS, Bradley LR, Burge JC: Changes in measured resting energy expenditure after Roux-en-Y gastric bypass for clinically severe obesity. Surgery 1997;122:943-949.

110 Wolff BS, Meirelles K, Meng Q, Pan M, Cooney RN: Roux-en-Y gastric bypass alters small intestine glutamine transport in the obese Zucker rat. Am J Physiol Gastrointest Liver Physiol 2009;297: G594-G601.

111 Stylopoulos N, Davis P, Pettit JD, Rattner DW Kaplan LM: Changes in serum ghrelin predict weight loss after Roux-en-Y gastric bypass in rats. Surg Endosc 2005;19:942-946.

112 Li Z, Zhang HY, Lv LX, Li DF, Dai JX, Sha O, Li WQ, Bai Y, Yuan L: Roux-en-Y gastric bypass promotes expression of PDX-1 and regeneration of beta-cells in Goto-Kakizaki rats. World $\mathrm{J}$ Gastroenterol 2010;16:2244-2251.

113 Guijarro A, Kirchner H, Meguid MM: Catabolic effects of gastric bypass in a diet-induced obese rat model. Curr Opin Clin Nutr Metab Care 2006; 9:423-435.

114 Guijarro A, Osei-Hyiaman D, Harvey-White J, Kunos G, Suzuki S, Nadtochiy S, Brookes PS, Meguid MM: Sustained weight loss after Rouxen-Y gastric bypass is characterized by down regulation of endocannabinoids and mitochondrial function. Ann Surg 2008;247:779-790.

115 Peng Y, Rideout DA, Rakita SS, Gower WR, Jr. You M, Murr MM: Does LKB1 mediate activation of hepatic AMP-protein kinase (AMPK) and sirtuin1 (SIRT1) after Roux-en-Y gastric bypass in obese rats? J Gastrointest Surg 2010;14:221-228.

116 Rideout DA, Peng Y, Rakita SS, Desai K, Gower WR Jr, You M, Murr MM: Roux-en-Y gastric bypass alters tumor necrosis factor-alpha but not adiponectin signaling in immediate postoperative period in obese rats 1 . Surg Obes Relat Dis 2010; 6:676-680.

117 Ramos EJ, Xu Y, Romanova I, Middleton F, Chen C, Quinn R, Inui A, Das U, Meguid MM: Is obesity an inflammatory disease? Surgery 2003;134: 329-335.

118 Romanova IV, Ramos EJ, Xu Y, Quinn R, Chen C, George ZM, Inui A, Das U, Meguid MM: Neurobiologic changes in the hypothalamus associated with weight loss after gastric bypass. J Am Coll Surg 2004;199:887-895

119 Young EA, Taylor MM, Taylor MK, McFee AS, Miller OL, Gleiser CA: Gastric stapling for morbid obesity: gastrointestinal response in a rat model. Am J Clin Nutr 1984;40:293-302. 